brança dos seres que passaram para o além, principalmente quando, pela vibração lustral da sua intelligencia, esses seres não encontraram na morte, a "morte" propriamente, mas uma forma vital mais perfeita - a immortalidade espiritual.

P.

\title{
NOSSA APRESENTAÇÃO
}

Assumo a direcção deșta "Révista", a pedido dos moços que a vêm redigindo. Não thes pude negar o meu auxilio, por obedecer a uma directriz traçada em meu espirito - de concorrer, com o meu pouco, para o brilho constante da juventude que estuda medicina em S. Paulo. Tenho ficado sempre a seu lado, nas questões que se têm suscitado e foi talvez, por esse motivo, conhecendo o amôr que lhes dedico, verdadeiro e santo, que se lembraram de pedir a minha coadjuvação. Não a regatearei, como nunca lhes neguei o que me pediram.

Não serei aqui, apenas, uma figura de prôa, como sóe acontecer, em regra, nos jornaes e revistas e sobretudo nos de ordem scientifica.

Procurarei, ao contrario, orientar-me para oriental-os, e farei o possivel para dirigil-os, de accordo com a orientação jornalistica moderna.

Não será difficil a minha situação, porque governar os moços é facil. Elles só têm aspirações puras. Inda não se macularam na vida. Guial-os é, portanto, agradavel; acompanhal-os em seus sonhos e devaneios, um consolo para os que têm cabellos brancos. É por isso que aqui estou e, confesso, aqui me sinto bem.

Saúdo a mocidade academica e comprometto-me a darthe a mão para leval-a ao objectivo de seus ideaes. 